\title{
Metallic element contents of biotite collected along the Nishiki river, Southwest Japan-Heavy metal concentration to caly minerals in aqueous solutions. II.
}

\author{
Setsuo Takeno, Asao Minami and Ryuj Kitagawa \\ Institute of Geology and Mineralogy, Faculty of Science, \\ Hiroshima University, Hiroshima, 730, Japan
}

(Received April 19, 1984: Accepted February 14, 1985)

\begin{abstract}
Metallic element contents of biotite collected along the Nishiki river, Southwest Japan, were investigated by means of atomic absorption spectrophotometry and the results obtained were examined from mineralogical and statistical view points. Biotite in the district is commonly altered to vermiculite and to lesser extent to vermiculite-chlorite interstratified mineral and kaolinite. The main variations of the chemical composition are mostly caused by decomposition and the vermiculitization of biotite.

The content of the representative interlayer cation, $\mathrm{K}$, depends on that of biotite in the parent granite. Rubidium behaves together with $\mathrm{K}$, so that the $\mathrm{Rb}$ fraction is almost constant in the interlayer cations $(\mathrm{K}$, $\mathrm{Na}, \mathrm{Ca}$ and $\mathrm{Rb}$ ), despite its low content (below 550ppm) of biotite.

Among the possible octahedral cations, substitution of $\mathrm{Fe}$ by $\mathrm{Mg}$ is remarkable. Contents of minor elements, such as $\mathrm{Cu}, \mathrm{Zn}$ and $\mathrm{Pb}$, vary locally but no geological evidences for explaining the local enrichments of these elements can be found. Correlation coefficients of $\mathrm{Fe}$ and $\mathrm{Zn}$ against $\mathrm{K}$ suggest that a part of the two elements are contained in the interlayer position.
\end{abstract}

\section{INTRODUCTION}

Takeno et al. (1981) demonstrated experimentally that metal ions concentrated remarkably to clay minerals when the minerals were suspended in aqueous solutions containing metal ions. In nature, metal ions in surface water, such as that of rivers and lakes, tend to concentrate in clay minerals suspended in and/or deposited from the water. However, we have little knowledge of this adsorption mechanism. For example, although clay minerals are commonly suspended or sedimented in rivers, few researches on detailed quantitative examinations of clay minerals in rivers have been done before. These clay minerals contain various metal ions and the concentration depends mainly on the geology of the district. Recent water pollutions caused by the extensive development of modern industries veil the natural distribution of the metal concentrations.

Most systematic researches on metal con- tents of surface water were carried out by Förstner and Müller (1974). Their remarkable contribution is that they distinguish the metal contents of clay particles from the metal ions contained in water. Their results clearly indicate that metal contents of clay constituents are on ppm level whereas those of water are on ppb level. Detailed mineralogical studies on the clay constituents are required. In our previous paper, heavy metal concentration of mica mineral $\left(2 \mathrm{M}_{1}\right.$ muscovite) under various aqueous conditions was examined experimentally (Takeno et al., 1981), and the results show that most of heavy metals such as $\mathrm{Zn}$, Co and $\mathrm{Cu}$ concentrate remarkably to the solid, i.e., mica mineral.

Examinations of metal contents of clay minerals in natural environment are rather difficult because of the minor amounts of a certain clay mineral in rivers and/or lakes. Among clay minerals, mica mineral is one of the most abundant in rivers, especially, if granitic rocks are 
developed in the district. As an example of such situations, the Nishiki river in Yamaguchi Prefecture, southwest Japan was selected for the investigation of metal contents of biotite from the mouth (Iwakuni city) to the head of the river, and the results of the analyses were examined statistically in relation to the geology of the district as well as to mineralogy. Biotite in the river sands was derived from the weathered part of granite developed in the district. The metal contents were examined for biotites both from river sands and weathered granite. Chemical variation of the biotite during the weathering process will not be treated in this paper.

\section{Outline of Geology and Samples}

Figure 1 shows geological map around the
Nishiki river together with the sampling localities. The geology of the district is studied in detail by Nishimura $(1971,1982)$, especially in relation to the regional metamorphism. According to Nishimura (1971), the basement of the geology of the district is composed of Paleozoic formation of the Tsuno group (Devonian to Carboniferous) and is called Sangun metamorphic rocks (Sg in Fig. 1). The Sangun metamorphic rocks are distributed in the central part of the district and consist of alternating beds of psammitic schists in the lower part and of basic schists in the upper part. The Nishiki group of Paleozoic formation (Permian) is also distributed in the northern part of the Sangun metamorphic rocks separated mainly by tectonic slides. The Nishiki group (Ns) is composed of slightly metamorphosed psammitic rocks, pelitic

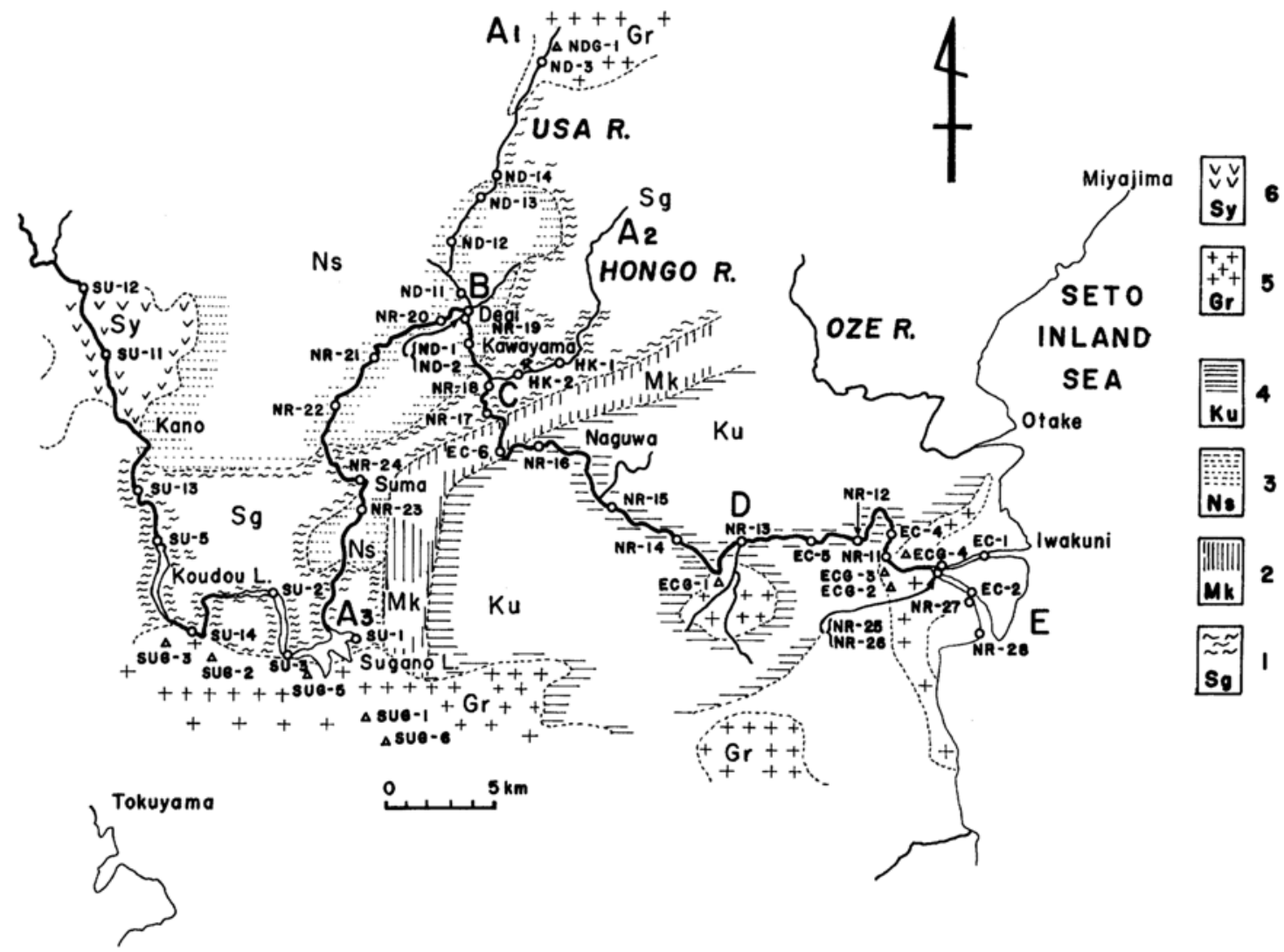

Fig. 1. Geological map and sampling localities of the Nishiki river district. 1: Sangun metamorphic rocks, 2: Mikawa group (Paleozoic), 3: Nishiki group (Paleozoic), 4: Kuga group (Mesozoic), 5: Granitic rocks (Mesozoic), 6: Rhyolitic pyroclastics (Mesozoic). 
rocks and acidic tuffs and is unconformably overlain by rhyolitic pyroclastics of Cretaceous age (Sy). Mesozoic formation of Kuga group (Triassic to Jurassic) is distributed widely in the southern part of the district. The rocks are separated by tectonic faults from the surrounding rocks and are composed of pelitic rocks, cherts and sandstones $(\mathrm{Ku})$. The Mikawa group of Permian age $(\mathrm{Mk})$ is distributed as a narrow belt between $\mathrm{Sg}$ and $\mathrm{Ku}$. These basement rocks are intruded by granitic rocks of the Hiroshima granite of late Cretaceous age (Gr) distributed widely in the southern and northeastern parts of the district. The granitic rocks are coarse grained biotite-granite composed of quartz, $\mathrm{K}$ feldspar, plagioclase and biotite. Hornblend is also a main constituent in the southern part of the Sugano lake. The average size of these minerals is about 1 to $5 \mathrm{~mm}$.

Along the Hongo river, the Kawayama mine of bedded cupriferous iron sulfides ore deposits in the Sangun metamorphic rocks (Takeno, $1965,1966)$ was once worked.

About $2 \mathrm{~kg}$ of river sands was collected from each locality shown in Fig. 1. A simple bottom sampler was used for collecting the samples from the Sugano lake. In addition to the samples from the rivers and lakes, some slightly weathered parts of the granite were also collected. Samples of ECG-, SUG- and NDG- are those from the weathered part of the granite from which biotite grains were transported into the river. These samples were washed with distilled water in order to remove impurities adhered to mica grains. Then, pure mica grains were picked up under the binocular microscope. These mica grains are usually smaller than about $2 \mathrm{~mm}$ in size with platy shape and dark brown to golden yellow in color. In the river sands, the grain size of biotite becomes considerably finer. Samples from the northwestern part of the district such as SU-11, 12 and 13 contain no mica grains since no granitic rocks are distributed in the upper reaches of the river. Samples along the Hongo river (A2 to C in Fig. 1), such as $\mathrm{HK}-1$ and $\mathrm{HK}-2$, contain only rounded or folded mica grains. These mica grains are muscovite of metamorphic origin and contain fine inclusions of plagioclase and quartz. Samples along the $\mathbf{A}_{3}$-B contain a very small amount of biotite suggesting that the biotite in the SUGgranite in the south-western part of the district is transported mainly to the south, towards Tokuyama city (Fig. 1). Along $A_{1}-B-C-D-E$, on the other hand, a systematic change in amounts of biotite in the river sands can be traced. The current direction of the river is almost perpendicular to the general trend of the geology of the district (NE-SW). Samples of NR-15 and NR-26 were taken from both sides (upper and lower) of a weir which separates the sea water. Therefore, samples from the reaches lower than

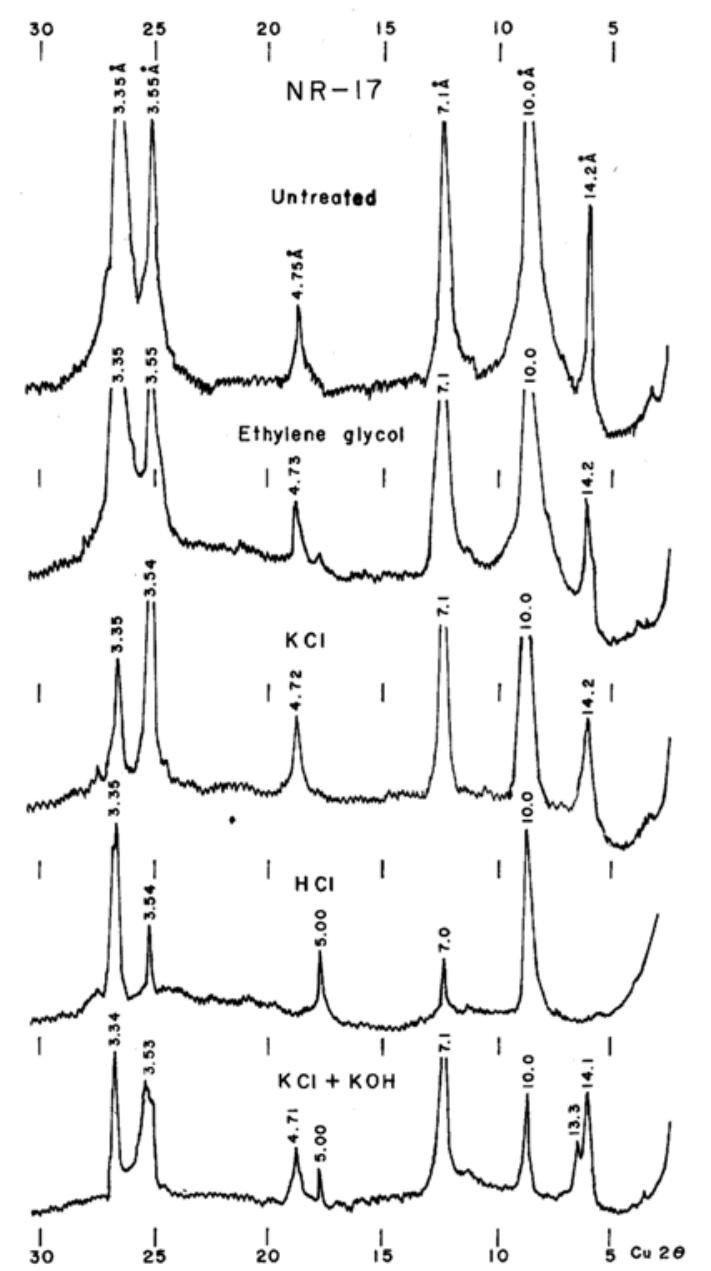

Fig. 2. X-ray powder diffraction patterns of biotite grains (NR-17) treated with some reagents. 
NR-25 of the river are sediments in brackish water. These mica grains collected were pulverized in an agate mortar for X-ray powder analyses.

X-ray powder patterns of the biotite grains generally reveal some extra reflections at about 14 and $7 \AA$ in addition to the basal reflections of mica mineral. In rare cases, weak relfections of interstratified mineral appear beyond $20 \AA$. Therefore, several treatments were done to identify the extra reflections. These treatments were as follows: 1) ethylene glycol, 2) $\mathrm{KCl}$ $(1 \mathrm{M})$ at $\left.95^{\circ} \mathrm{C}(1 \mathrm{~h}), 3\right) \mathrm{KCl}(1 \mathrm{M})+\mathrm{KOH}(1 \mathrm{M})$ at $\left.95^{\circ} \mathrm{C}(1 \mathrm{~h}), 4\right) \mathrm{HCl}(6 \mathrm{M})(1 \mathrm{~h})$ and 5$)$ heating at $300^{\circ}$ and $500^{\circ} \mathrm{C}(1 \mathrm{~h})$ in air. An example of the results of these treatments for one sample is shown in Fig. 2. Except two biotites from relatively fresh granite, all biotite grains exhibit distinct reflections at $14 \AA$. The $14 \AA$ spacing does not expand by ethylene glycol treatment indicating absence of smectite (Harward and Brindley, 1965). Therefore, the $14 \AA$ reflection can be ascribed to vermiculite or chlorite. By the $\mathrm{KCl}$ treatment, the intensity of the $14 \AA$ reflection becomes weak but remains clearly, suggesting the existence of chlorite, since $14 \AA$ reflection of vermiculite shifts toward $10 \AA$ by the treatment (Sudo, 1974). Existence of kaolinite should be confirmed by some treatments since the second order reflections of vermiculite and chlorite appear also at $7 \AA$. For this purpose, the $\mathrm{HCl}$ treatment was done, because chlorite and vermiculite are decomposed by warm $\mathrm{HCl}$ whereas kaolinite is resistive (Brindley, 1961). As is seen in Fig. 2, the 14 $\AA$ reflection disappears by the $\mathrm{HCl}$ treatment but the $7 \AA$ reflection remains in the case of NR-7 showing the existence of some kaolinite. Further confirmation of kaolinite was done by heating at $500^{\circ} \mathrm{C}$ for one hour. Movement of some reflections from $14 \AA$ to $13.3 \AA$ by the $\mathrm{KCl}+\mathrm{KOH}$ treatment suggests the existence of vermiculite-chlorite interstratified mineral (mixed-layer mineral; Sudo, 1974). Therefore, chlorite found by the $\mathrm{KCl}$ treatment is that of vermiculite-chlorite interstratified mineral. Figure 3 shows the most representative X-ray powder patterns of biotite grains from granite and from river sands. As the results of the above treatments, the constituent minerals are found to be mainly mica mineral $(10 \AA)$ and vermiculite $(14 \AA)$ with small amounts of vermiculite-

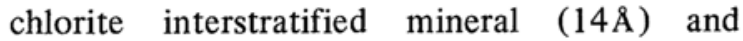
kaolinite ( $7 \AA)$. The vermiculite-chlorite interstratified mineral is found mainly in river sands. Mica grains of $\mathrm{HK}-1$ and $\mathrm{HK}-2$ (along $\mathrm{A}_{2}-\mathrm{C}$ ) derived from the Sangun metamorphic rocks are composed of mixtures of very fine grained mica clay mineral (muscovite), quartz and plagioclase.

About $100 \mathrm{mg}$ of these biotite grains was dissolved in mixed hydrofluoric and hydrochloric acids and $50 \mathrm{ml}$ solutions were obtained.

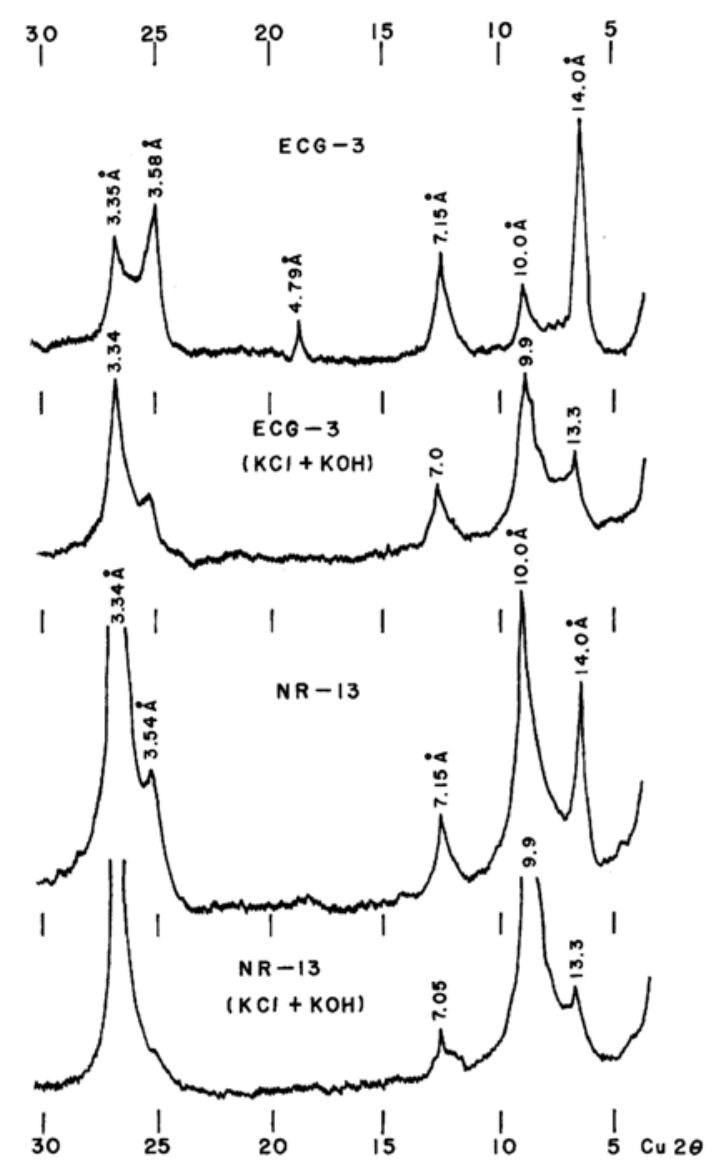

Fig. 3. X-ray powder diffraction patterns of biotite grains collected from granite (ECG-3) and from river sands (NR-13). 
The concentrations of elements were determined by atomic absorption using Model AA-646 atomic-absorption spectrophotometer by the flame method. Minor elements such as $\mathrm{Cr}$, Co, $\mathrm{Ni}, \mathrm{Cu}$ and $\mathrm{Pb}$ were measured by carbon-tube flameless method.

\section{EXPERIMENTAL RESULTS}

Metal contents of biotite are listed in Table 1 in ppm except for $\mathrm{K}, \mathrm{Na}, \mathrm{Mg}, \mathrm{Mn}$ and $\mathrm{Fe}$ (wt.\%). Among the measured 14 elements, it is generally accepted that the first 4 elements $(\mathrm{K}, \mathrm{Na}, \mathrm{Ca}$ and $\mathrm{Rb}$ ) occupy the interlayer position and the rest belong to the octahedral positions (e.g. Deerr et al., 1962). The two main constituent elements of the mica mineral, $\mathrm{Si}$ and $\mathrm{Al}$, could not be measured because of technical difficulties by atomic-absorption method.

For the comparative study, metal contents of biotite in the typical Hiroshima granite collected in the western part of Hiroshima city (Koi-machi) were also examined. Three samples of A-1, A-4 and A-6 in Table 1 are taken from the weathered part of granite, $0-10 \mathrm{~cm}, 40 \mathrm{~cm}$ and $60 \mathrm{~cm}$ depths from the surface of the outcrop, respectively. Characteristics of the variation of metal content of biotite from the depths to the surface are now being studied and will be reported elsewhere. The numbers from 1 to 32 in the Table 1 are samples collected along the $\mathrm{A}_{1}-\mathrm{B}-\mathrm{C}-\mathrm{D}-\mathrm{E}$ in Fig. 1 (from the lower to the upper reaches) together with those of the parent granite of the district. The mean and standard deviation (S.D.) in Table 1 were calculated from the data of these 32 samples since biotites of these localities probably constitute a series as was described previously. In general, the $\mathrm{pH}$ value of the river water is in the range between 7.0 and 8.0 throughout the year (Iwakuni city, 1979). In Table 1 , the first 5 samples are those from brackish water. The Na contents of these samples are higher than those of the adjacent samples taken from fresh water (NR-25, NR-11) and adsorption of $\mathrm{Na}$ is compensated by $\mathrm{Ca}$ release and adsorption of some metals such as $\mathrm{Rb}, \mathrm{Li}$ and $\mathrm{Zn}$.
As some typicl examples of the major interlayer cations and minor octahedral cations, the distributions of $\mathrm{K}$ and $\mathrm{Zn}$ contents are shown schematically in Figs. 4 and 5, respectively. In these figures, $\mathrm{K}$ and $\mathrm{Zn}$ contents of mica grains collected from the river sands are represented by the length of thick lines perpendicular to the river current. The average $\mathrm{K}$ and $\mathrm{Zn}$ contents of biotite obtained from the granites are also shown (NDG-, SUG- and ECGin Figs. 4 and 5). Potassium is the most representative interlayer cation of mica minerals and the variation of the content may probably reflect the degree of alteration and/or breakdown. It can be said that $\mathrm{K}$ content of mica minerals in river sands relates largely to those of biotite in the parent granites, i.e., those from $A_{1}$ to $B, A_{3}$ to $B$ and $D$ to $E$ are similar to those of NDG-, SUG- and ECG-biotite, respectively. In other words, $\mathrm{K}$ content of biotite is held almost constant even after they are transported into river water and brackish water. Unusually large $\mathrm{K}$ contents of those from $\mathrm{A}_{2}$ to $\mathrm{C}$ are due to differnet species of the mica mineral, i.e., muscovite of metamorphic origin as described previously. The variation range of $\mathrm{K}$ content is relatively small (between 1.24 and 5.12 wt.\% except those of muscovite) compared with other cations. Moreover, the average $\mathrm{K}$ content is $2.95 \mathrm{wt} . \%$ (Table 1) and the value is far lower than that of fresh biotite in granite. According to Deer et al. (1962), the K content of fresh biotite in granitic rocks is in the range between 5.8 and $7.5 \mathrm{wt} . \%$ (equivalent to about 7.0-9.0wt.\% of $\mathrm{K}_{2} \mathrm{O}$ ). As is seen in Table 1, a considerable amount of $\mathrm{K}$ release from biotite structure is found even in the parent granite (weathered part). That is, the most part of the $\mathrm{K}$ release has proceeded before the transportation of the biotite into the river. Therefore, during the weathering of the host granite, the $\mathrm{K}$ release has proceeded to a large extent.

$\mathrm{Zn}$ content, on the other hand, varies considerably independent of the content of those of biotite in the parent granites as shown in Fig. 5. There are some possibilities that relatively high $\mathrm{Zn}$ contents from $\mathrm{C}$ to $\mathrm{D}$ in Fig. 5 are 
Table 1. Metallic element contents (in ppm) of mica minerals collected from the Nishiki river district, except $\mathrm{K}, \mathrm{Na}, \mathrm{Mg}$ and $\mathrm{Fe}$ contents which are given in wt.\% (marked by star). The calculations of the Mean and $S$. D. (Standard deviation) were done with the numbered 32 samples collected along $A_{1}-B-C$ D-E (Nos. 1-24) and from the parent granite (Nos. 25-32).

\begin{tabular}{|c|c|c|c|c|c|c|c|c|c|c|c|c|c|c|c|}
\hline \multicolumn{2}{|c|}{ Samples } & $\mathrm{K}^{*}$ & $\mathrm{Na}^{*}$ & $\mathrm{Ca}$ & $\mathrm{Rb}$ & $\mathrm{Li}$ & $\mathrm{Mg}^{*}$ & $\mathrm{Cr}$ & $\mathrm{Mn}^{*}$ & $\mathrm{Fe}^{*}$ & Co & $\mathrm{Ni}$ & $\mathrm{Cu}$ & $\mathrm{Zn}$ & $\mathrm{Pb}$ \\
\hline 1 & NR-28 & 4.11 & 0.33 & 292 & 456 & 439 & 2.99 & 20 & 0.27 & 16.66 & 30 & 0 & 41 & 728 & 10 \\
\hline 2 & NR-27 & 3.81 & 0.32 & 194 & 547 & 485 & 2.02 & 11 & 0.29 & 18.45 & 17 & 0 & 38 & 917 & 4 \\
\hline 3 & EC-2 & 3.87 & 0.59 & 193 & 516 & 474 & 2.10 & 36 & 0.32 & 17.40 & 23 & 10 & 50 & 701 & 16 \\
\hline 4 & EC-1 & 3.83 & 0.22 & 202 & 367 & 230 & 2.40 & 55 & 0.31 & 14.90 & 29 & 21 & 40 & 488 & 10 \\
\hline 5 & NR-26 & 4.10 & 0.18 & 365 & 356 & 243 & 3.00 & 24 & 0.27 & 14.27 & 21 & 0 & 57 & 471 & 0 \\
\hline 6 & NR-25 & 3.43 & 0.08 & 586 & 379 & 287 & 2.57 & 0 & 0.27 & 15.58 & 21 & 0 & 43 & 518 & 0 \\
\hline 7 & NR-11A & 4.16 & 0.07 & 563 & 400 & 157 & 2.71 & 25 & 0.26 & 15.54 & 21 & 0 & 27 & 359 & 1 \\
\hline 8 & NR-11B & 3.64 & 0.08 & 609 & 366 & 293 & 2.88 & 25 & 0.25 & 14.95 & 22 & 0 & 30 & 338 & 1 \\
\hline 9 & EC-4 & 5.12 & 0.35 & 431 & 383 & 229 & 3.50 & 52 & 0.36 & 16.40 & 22 & 7 & 91 & 421 & 5 \\
\hline 10 & NR-12 & 3.66 & 0.09 & 687 & 370 & 210 & 2.96 & 23 & 0.26 & 15.47 & 17 & 0 & 34 & 353 & 4 \\
\hline 11 & EC-5B & 4.46 & 0.23 & 609 & 403 & 224 & 3.00 & 57 & 0.31 & 15.20 & 24 & 8 & 38 & 330 & 3 \\
\hline 12 & EC-5G & 3.67 & 0.17 & 398 & 319 & 180 & 2.60 & 47 & 0.26 & 14.20 & 23 & 17 & 16 & 354 & 7 \\
\hline 13 & NR-13 & 3.56 & 0.18 & 705 & 361 & 350 & 2.32 & 15 & 0.29 & 15.70 & 18 & 0 & 85 & 729 & 34 \\
\hline 14 & NR-14 & 2.40 & 0.22 & 788 & 212 & 274 & 0.46 & 5 & 0.36 & 17.46 & 2 & 0 & 71 & 911 & 105 \\
\hline 15 & NR-15 & 3.06 & 0.14 & 439 & 365 & 418 & 1.35 & 10 & 0.34 & 17.02 & 13 & 0 & 84 & 439 & 49 \\
\hline 16 & NR-16 & 2.02 & 0.22 & 362 & 199 & 332 & 0.81 & 8 & 0.51 & 18.65 & 9 & 0 & 99 & 758 & 77 \\
\hline 17 & EC-6 & 1.84 & 0.52 & 450 & 195 & 406 & 1.30 & 0 & 0.54 & 24.30 & 10 & 3 & 68 & 1278 & 43 \\
\hline 18 & NR-17 & 1.76 & 0.16 & 603 & 141 & 319 & 0.91 & 4 & 0.40 & 20.01 & 7 & 0 & 47 & 940 & 64 \\
\hline 19 & NR-18 & 2.81 & 0.17 & 420 & 333 & 440 & 1.24 & 6 & 0.38 & 18.22 & 8 & 0 & 24 & 811 & 45 \\
\hline 20 & NR-18 & 1.84 & 0.23 & 503 & 143 & 365 & 0.97 & 7 & 0.40 & 20.29 & 7 & 0 & 26 & 915 & 63 \\
\hline & ND-2 & 2.59 & 0.63 & 1227 & 159 & 184 & 3.90 & 125 & 0.35 & 16.40 & 39 & 34 & 186 & 541 & 9 \\
\hline & NR-21 & 2.20 & 0.17 & 534 & 134 & 177 & 2.90 & 73 & 0.26 & 14.45 & 27 & 0 & 116 & 413 & 13 \\
\hline & NR-22 & 1.86 & 0.30 & 1460 & 126 & 206 & 3.60 & 61 & 0.35 & 17.62 & 32 & 0 & 83 & 429 & 5 \\
\hline & NR-24 & 3.13 & 0.11 & 847 & 288 & 251 & 2.69 & 43 & 0.23 & 13.85 & 27 & 0 & 70 & 376 & 3 \\
\hline & NR-23 & 3.87 & 0.13 & 649 & 403 & 366 & 2.57 & 0 & 0.35 & 15.12 & 22 & 0 & 45 & 476 & 1 \\
\hline & SU-14 & 2.86 & 0.23 & 1601 & 173 & 113 & 3.08 & 52 & 0.16 & 13.40 & 16 & 0 & 84 & 294 & 8 \\
\hline & $\mathrm{HK}-2$ & 5.67 & 1.29 & 110 & 196 & 80 & 0.80 & 79 & 0.10 & 4.70 & 9 & 21 & 47 & 177 & 6 \\
\hline & HK-1 & 4.46 & 0.33 & 184 & 171 & 80 & 0.90 & 83 & 0.10 & 4.80 & 9 & 23 & 67 & 167 & 6 \\
\hline 21 & ND-1 & 1.25 & 0.39 & 681 & 131 & 370 & 1.10 & 36 & 0.52 & 20.70 & 12 & 20 & 89 & 977 & 65 \\
\hline 22 & ND-11 & 1.40 & 0.19 & 345 & 193 & 372 & 0.28 & 0 & .0 .40 & 19.89 & 2 & 0 & 37 & 926 & 87 \\
\hline 23 & ND-13 & 1.28 & 0.29 & 382 & 178 & 436 & 0.32 & 0 & 0.41 & 20.82 & 1 & 0 & 63 & 1201 & 88 \\
\hline 24 & ND-3 & 1.57 & 0.39 & 232 & 148 & 327 & 0.70 & 9 & 0.40 & 19.00 & 4 & 0 & 40 & 899 & 56 \\
\hline 25 & NDG-1 & 1.24 & 0.23 & 133 & 102 & 115 & 0.70 & 10 & 0.27 & 18.00 & 5 & 2 & 35 & 922 & 48 \\
\hline 26 & ECG-1 & 3.79 & 0.24 & 1660 & 246 & 198 & 3.50 & 55 & 0.24 & 14.50 & 28 & 7 & 12 & 218 & 2 \\
\hline 27 & ECG-2 & 3.95 & 0.25 & 107 & 338 & 187 & 0.70 & 0 & 0.27 & 17.10 & 3 & 1 & 7 & 614 & 42 \\
\hline 28 & ECG-3 & 2.04 & 0.15 & 57 & 367 & 438 & 0.60 & 5 & 0.28 & 18.20 & 5 & 4 & 8 & 725 & 3 \\
\hline 29 & ECG-4 & 2.03 & 0.19 & 299 & - & - & 1.40 & 29 & 0.49 & 20.70 & 5 & 4 & 8 & 707 & 2 \\
\hline 30 & SUG-2 & 2.31 & 0.23 & 429 & 205 & 135 & 2.20 & 106 & 0.19 & 11.80 & 23 & 65 & 12 & 269 & 8 \\
\hline 31 & SUG-5 & 3.65 & 0.23 & 1422 & 398 & 153 & 3.10 & 152 & 0.24 & 14.30 & 26 & 21 & 27 & 310 & 5 \\
\hline 32 & SUG-6 & 2.88 & 0.18 & 67 & 340 & 322 & 0.80 & 17 & 0.24 & 10.70 & 7 & 3 & 78 & 437 & 3 \\
\hline & A-1 & 4.52 & 0.44 & 2970 & 188 & 218 & 2.6 & 8 & 0.28 & 18.56 & 0 & 0 & 59 & 461 & 5 \\
\hline & A-4 & 4.35 & 0.50 & 3950 & 368 & 312 & 2.63 & 10 & 0.30 & 19.00 & 0 & 0 & 28 & 523 & 3 \\
\hline & A- 6 & 4.10 & 0.47 & 4702 & 297 & 281 & 2.62 & 8 & 0.29 & 18.74 & 0 & 0 & 21 & 522 & 5 \\
\hline & MEAN & 2.95 & 0.24 & 475 & 296 & 294 & 1. & 27 & 0.33 & 16.9 & 15 & 6 & 44 & 655 & 30 \\
\hline & S.D & 1.11 & 0.12 & 342 & 128 & 120 & 1.08 & 33 & 0.09 & 2.99 & 9 & 13 & 27 & 284 & 32 \\
\hline
\end{tabular}

caused by the existence of the Kawayama mine, in which $\mathrm{Zn}$ was one of the most important products (about $1.0 \mathrm{wt}$ \% $\mathrm{Zn}$ in raw ore). However, the influence of the mine should be considered together with the mobility (easiness of release or adsorption) of the elements which will be discussed later based on correlation coefficients of $\mathrm{Zn}$ against the other elements.

Examinations of $\mathrm{Co}, \mathrm{Cu}$ and $\mathrm{Pb}$ distributions strongly suggest that these elements sensitively reflect the local enrichments of these ions. For example, the cause of high Co content between 


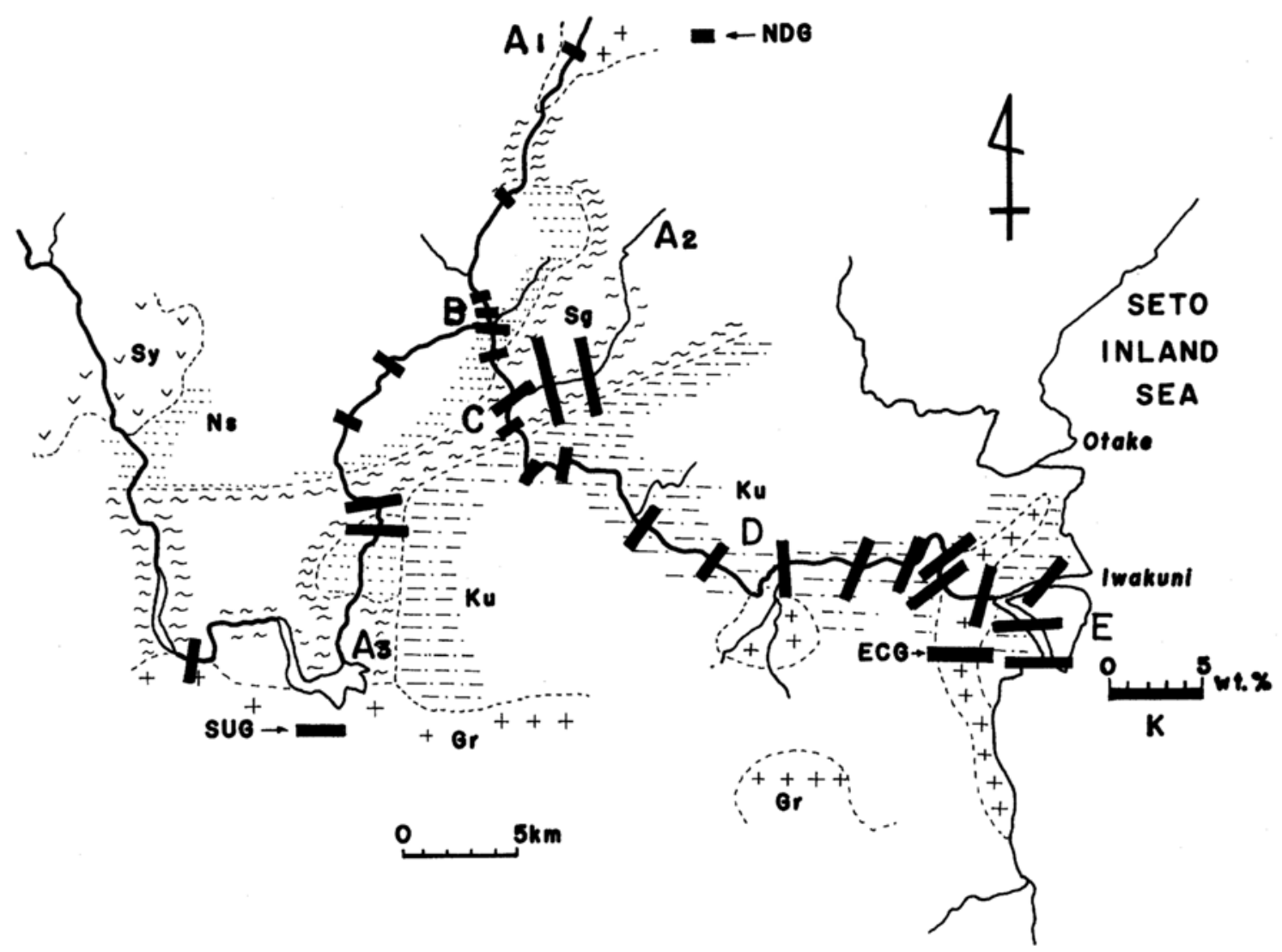

Fig. 4. Schematic representation of $K$ content of mica minerals along the Nishiki river. The length of the thick lines represent $K$ contents.

$A_{3}$ and $B$ (Co contents of NR-23, -24, -22, -21 and ND-2 are 22, 27, 32, 27 and $39 \mathrm{ppm}$, respectively) will probably be ascribed to the local enrichment since the Co content of biotite in the parent granite is very low. The high $\mathrm{Pb}$ contents between $\mathrm{B}$ and $\mathrm{D}$ are ascribed also to the same cause. The cause of such local enrichment of certain elements is not sure at the present stage, since no special hydrothermal activities are found in these subdistricts. Human activities, such as small factories can also be one of the causes.

Correlation coefficient between two elements were calculated with 32 data numbered in Table 1 and the results are shown in Table 2. These 32 samples are collected along $A_{1}-B-C$ -D-E (Fig. 1) together with those of the parent granite, and all of these may probably have serial genetical relations with each other. The same coefficients were also calculated with 24 samples which are restricted to the river sands along the same line and the results are shown in Table 3. In the case of 32 samples, the significance level of the coefficient is statistically recognizable above 0.325 with $5 \%$ risk and above 0.418 with $1 \%$ risk (Fisher, 1963). Therefore, it can be safely said that two elements have surely certain correlations when the values exceed 0.50. In Table 2, the most intimate correlations are found between K-Rb (0.82), Mg-Co (0.93), Mn-Fe (0.84) and Fe-Zn (0.86). The first pair, K-Rb, shows that the both elements are released from or introduced to the interlayer position of biotite structure together. This fact has been reasonably accepted since the intimate geochemical relations between $\mathrm{Rb}$ and K were pointed out already by Mason (1966). $\mathrm{Rb}$ forms no minerals of its own except in few 


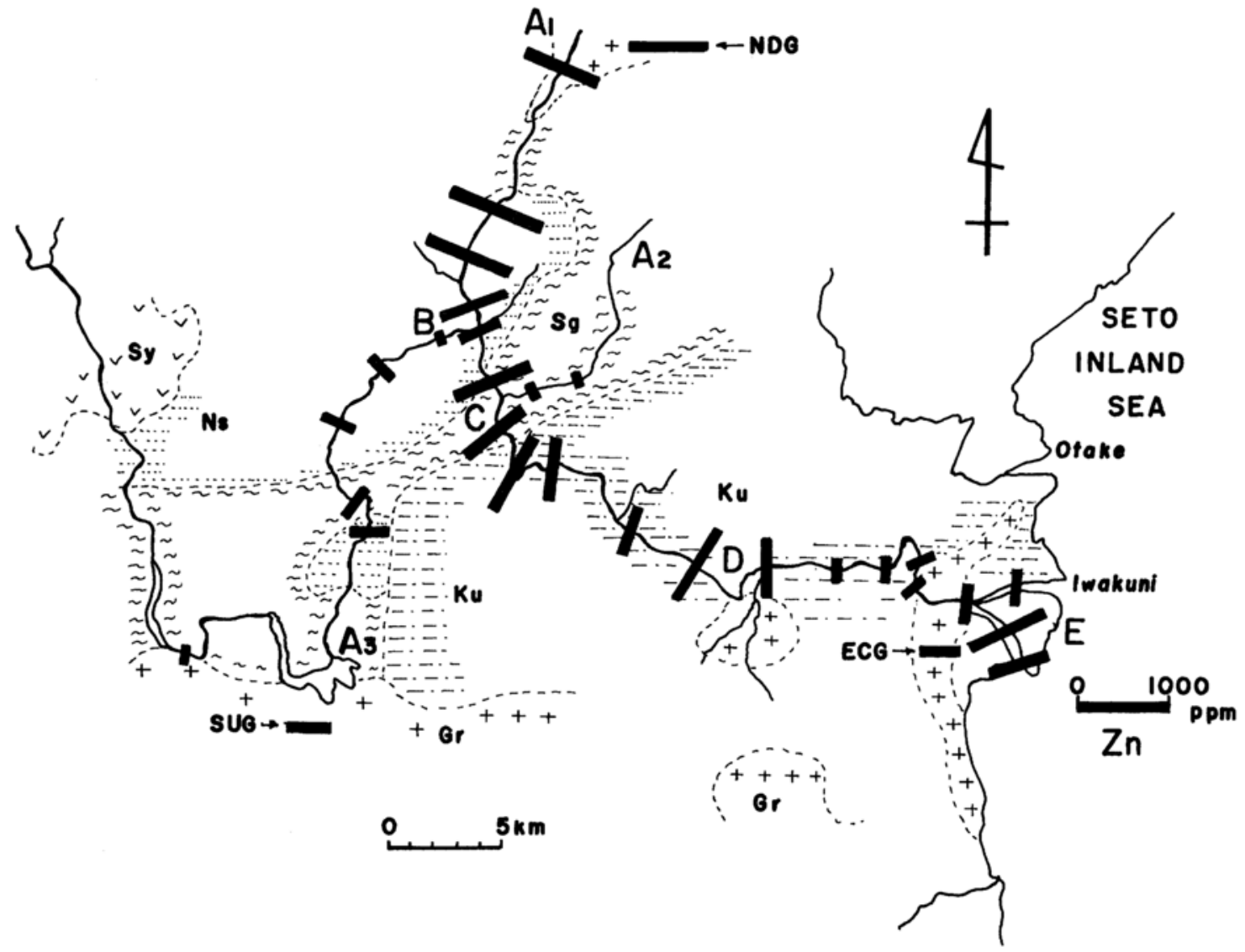

Fig. 5. Schematic representation of $\mathrm{Zn}$ content of mica minerals along the Nishiki river.

Table 2. Correlation coefficients between two elements, calculated on the numbered 32 samples in Table 1 (see text)

\begin{tabular}{|l|r|r|r|r|r|r|r|r|r|r|r|r|r|r|}
\hline & \multicolumn{1}{|c|}{$\mathrm{K}$} & \multicolumn{1}{|c|}{$\mathrm{Na}$} & \multicolumn{1}{c|}{$\mathrm{Ca}$} & $\mathrm{Rb}$ & $\mathrm{Li}$ & $\mathrm{Mg}$ & $\mathrm{Cr}$ & $\mathrm{Mn}$ & $\mathrm{Fe}$ & $\mathrm{Co}$ & $\mathrm{Ni}$ & $\mathrm{Cu}$ & $\mathrm{Zu}$ & $\mathrm{Pb}$ \\
\hline $\mathrm{K}$ & \multicolumn{1}{|c|}{1.00} & & & & & & & & & & & & & \\
\hline $\mathrm{Na}$ & -0.11 & 1.00 & & & & & & & & & & & & \\
\hline $\mathrm{Ca}$ & 0.18 & -0.15 & 1.00 & & & & & & & & & & & \\
\hline $\mathrm{Rb}$ & 0.82 & -0.02 & -0.04 & 1.00 & & & & & & & & & & \\
\hline $\mathrm{Li}$ & -0.20 & 0.38 & -0.28 & 0.23 & 1.00 & & & & & & & & & \\
\hline $\mathrm{Mg}$ & 0.82 & -0.11 & 0.46 & 0.58 & -0.34 & 1.00 & & & & & & & & \\
\hline $\mathrm{Cr}$ & 0.34 & 0.05 & 0.50 & 0.19 & -0.50 & 0.57 & 1.00 & & & & & & & \\
\hline $\mathrm{Mn}$ & -0.58 & 0.41 & -0.13 & -0.56 & 0.33 & -0.51 & -0.38 & 1.00 & & & & & & \\
\hline $\mathrm{Fe}$ & -0.60 & 0.42 & -0.17 & -0.48 & 0.43 & -0.56 & -0.52 & 0.84 & 1.00 & & & & & \\
\hline $\mathrm{Co}$ & 0.75 & 0.00 & 0.38 & 0.61 & -0.22 & 0.93 & 0.62 & -0.52 & -0.58 & 1.00 & & & & \\
\hline $\mathrm{Ni}$ & -0.00 & 0.13 & 0.11 & -0.07 & -0.36 & 0.22 & 0.73 & -0.25 & -0.39 & 0.38 & 1.00 & & & \\
\hline $\mathrm{Cu}$ & -0.06 & 0.27 & -0.06 & -0.02 & 0.37 & -0.13 & -0.21 & 0.42 & 0.13 & -0.09 & -0.21 & 1.00 & & \\
\hline $\mathrm{Zn}$ & -0.70 & 0.46 & -0.34 & -0.46 & 0.56 & -0.72 & -0.60 & 0.71 & 0.86 & -0.68 & -0.35 & 0.26 & 1.00 & \\
\hline $\mathrm{Pb}$ & -0.69 & 0.18 & -0.06 & -0.61 & 0.33 & -0.77 & -0.45 & 0.61 & 0.60 & -0.71 & -0.24 & 0.38 & 0.71 & 1.00 \\
\hline
\end{tabular}

cases and, in igneous rocks, it is present in mica minerals (mainly biotite) and potash feldspar. After Mason (1966), $\mathrm{K}$ is the only major element which can be replaced by $\mathrm{Rb}$ at the crys- tallization stage of minerals. The present results suggest that $\mathrm{Rb}$ behaves in association with $K$ during the decomposition or alteration process of biotite. The coefficient increases to 0.87 
Table 3. Correlation coefficients between two elements, calculated on the 24 samples (Nos. 1-24 in Table 1) (see text)

\begin{tabular}{|l|r|r|r|r|r|r|r|r|r|r|r|r|r|r|}
\hline & \multicolumn{1}{|c|}{$\mathrm{K}$} & \multicolumn{1}{|c|}{$\mathrm{Na}$} & $\mathrm{Ca}$ & $\mathrm{Rb}$ & $\mathrm{Li}$ & $\mathrm{Mg}$ & $\mathrm{Cr}$ & $\mathrm{Mn}$ & $\mathrm{Fe}$ & $\mathrm{Co}$ & $\mathrm{Ni}$ & $\mathrm{Cu}$ & $\mathrm{Zn}$ & $\mathrm{Pb}$ \\
\hline $\mathrm{K}$ & 1.00 & & & & & & & & & & & & & \\
\hline $\mathrm{Na}$ & -0.17 & 1.00 & & & & & & & & & & & & \\
\hline $\mathrm{Ca}$ & -0.07 & -0.45 & 1.00 & & & & & & & & & & & \\
\hline $\mathrm{Rb}$ & 0.87 & -0.03 & -0.27 & 1.00 & & & & & & & & & & \\
\hline $\mathrm{Li}$ & -0.39 & 0.52 & -0.39 & 0.01 & 1.00 & & & & & & & & & \\
\hline $\mathrm{Mg}$ & 0.92 & -0.19 & 0.03 & 0.75 & -0.48 & 1.00 & & & & & & & & \\
\hline $\mathrm{Cr}$ & 0.64 & 0.10 & -0.08 & 0.42 & -0.50 & 0.66 & 1.00 & & & & & & & \\
\hline $\mathrm{Mn}$ & -0.76 & 0.49 & -0.01 & -0.74 & 0.37 & -0.71 & -0.33 & 1.00 & & & & & & \\
\hline $\mathrm{Fe}$ & -0.80 & 0.53 & -0.08 & -0.63 & 0.60 & -0.75 & -0.57 & 0.86 & 1.00 & & & & & \\
\hline $\mathrm{Co}$ & 0.86 & -0.06 & -0.16 & 0.77 & -0.33 & 0.91 & 0.72 & -0.65 & -0.71 & 1.00 & & & & \\
\hline $\mathrm{Ni}$ & 0.13 & 0.30 & -0.14 & 0.03 & -0.24 & 0.19 & 0.75 & 0.08 & -0.15 & 0.40 & 1.00 & & & \\
\hline $\mathrm{Cu}$ & -0.15 & 0.30 & 0.16 & -0.20 & 0.18 & -0.18 & -0.05 & 0.50 & 0.24 & -0.18 & 0.04 & 1.00 & & \\
\hline $\mathrm{Zn}$ & -0.79 & 0.53 & -0.13 & -0.58 & 0.67 & -0.78 & -0.63 & 0.73 & 0.91 & -0.71 & -0.18 & 0.22 & 1.00 & \\
\hline $\mathrm{Pb}$ & -0.86 & 0.14 & 0.15 & -0.79 & 0.36 & -0.94 & -0.58 & 0.71 & 0.67 & -0.89 & -0.19 & 0.35 & 0.72 & 1.00 \\
\hline
\end{tabular}

when samples are restricted to the river sands (see, Table 3). The other interlayer cations such as $\mathrm{Na}$ and $\mathrm{Ca}$ have very low coefficients to the other elements even to $\mathrm{K}$ and $\mathrm{Rb}$. This suggests that the two elements are introduced or released from biotite structure independently as far as the correlation coefficients are concerned. The rest three pairs (Mg-Co, $\mathrm{Mn}-\mathrm{Fe}, \mathrm{Fe}-\mathrm{Zn}$ ) are considered to be the interrelations among the octahedral cations. These elements behave in association with each other, since the values are positive. Special attention should be paied to the high positive value of $\mathrm{Fe}-\mathrm{Zn}$ combination. These two elements have almost the same coefficients to the other elements, i.e., the both elements have high negative values to the other interlayer cations, especially to $\mathrm{K}(\mathrm{Fe}-\mathrm{K}=-0.60$, and $\mathrm{Zn}-\mathrm{K}=-0.70$ ), which means that when $\mathrm{K}$ is released from the structure, $\mathrm{Fe}$ and $\mathrm{Zn}$ are introduced to the structure. These high negative values against $\mathrm{K}$ indicate that a part of $\mathrm{Fe}$ and $\mathrm{Zn}$ occupy the interlayer position replacing $\mathrm{K}$. This can happen in the case of the mineral vermiculite whose formula is represented as

$\left(\mathrm{E}_{0.6-0.9}\right) \mathrm{Mg}_{3}(\mathrm{SiAl})_{4} \mathrm{O}_{10}(\mathrm{OH})_{2} \mathrm{nH}_{2} \mathrm{O}$,

where $\mathrm{E}$ is exchangeable cations (Sudo, 1974). The composition, charge relations and cation exchange capacity of vermiculite can be interpreted as replacement of $\mathrm{K}$ by some bivalent cations (Foster, 1963; Nagasawa, 1972). Therefore, under the condition of high $\mathrm{Zn}$ content of river water, $\mathrm{Zn}$ content of the mineral (biotite + vermiculite) may easily increase replacing the interlayer cations as well as the octahedral cations. $\mathrm{Fe}$ and $\mathrm{Zn}$ exhibit the same tendencies against the possible octabedral cations, i.e., negative values to $\mathrm{Mg}, \mathrm{Cr}$ and $\mathrm{Co}$ and high positive values to $\mathrm{Li}, \mathrm{Mn}$ and $\mathrm{Pb}$. These correlation values indicate that the two elements are released from the biotite (or vermiculite) structure together with $\mathrm{Li}, \mathrm{Mn}$ and $\mathrm{Pb}$ but are replaced by $\mathrm{Mg}$ with $\mathrm{Cr}$ and $\mathrm{Co}$ whose ionic radii are almost equal to those of $\mathrm{Fe}^{2+}$ and $\mathrm{Zn}^{2+}$. It may be also concluded that $\mathrm{Pb}$ replaces partly the interlayer cations, especially $\mathrm{K}$ and $\mathrm{Rb}$, since $\mathrm{Pb}$ has negative correlation coefficients against the two elements, and $\mathrm{Pb}^{2+}$ has a relatively large ionic radius compared with those of octahedral cations. In natural silicates, $\mathrm{Pb}$ (whose ionic radius is $1.2 \AA$ ) displays diadochic substitution for K (1.33 $\AA$ ) (Ringwood, 1955). However, the greater electronegativity of $\mathrm{Pb}$ (1.8) compared with $\mathrm{K}(0.8)$ decreases the amount of the substitution (Mason, 1966; Ringwood, 1955). These factors seem to be valid even in natural aqueous environments. The highest negative correlation is found between $\mathrm{Pb}$ and $\mathrm{Mg}(-0.76$ in Table 2 and -0.91 in Table 3). Moreover, the two elements show reverse correlations to other elements. For example, $\mathrm{Pb}$ has high negative values against $\mathrm{K}, \mathrm{Rb}$ and $\mathrm{Co}$ whereas those of $\mathrm{Mg}$ are positive. The satisfactory explanation for the intimate correlations between the two elements remains to be solved. 

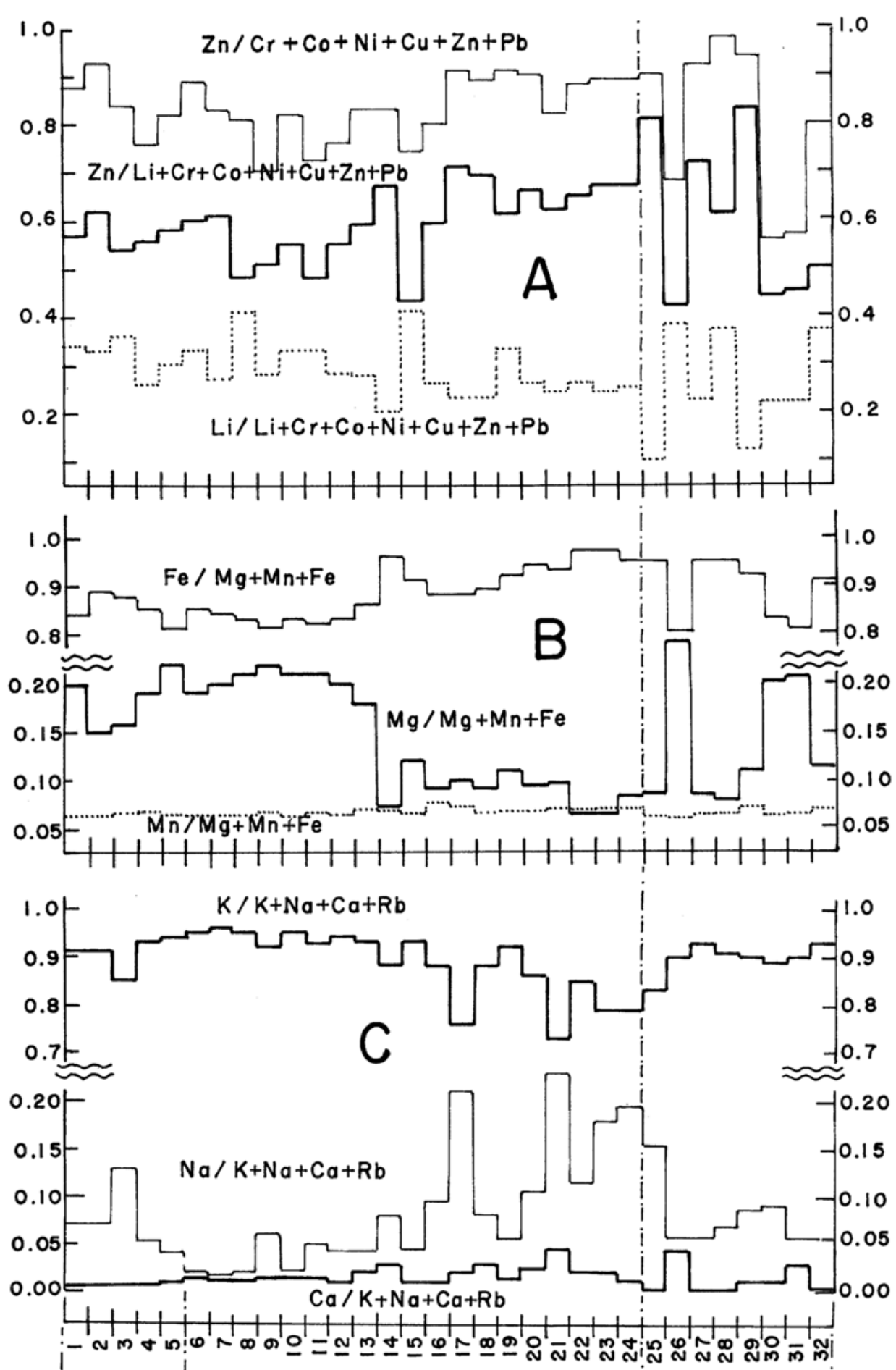

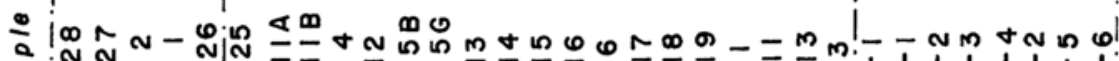

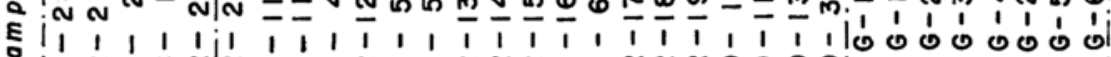

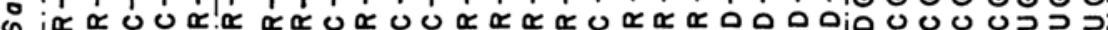

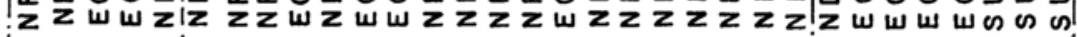
labrackishai - Fresh water $\longrightarrow$ i-Granito $\longrightarrow$ i

Fig. 6. Multiple correlations among the possible octahedral cations (A and B) and the interlayer cations (C). 
To be noted is that the coefficient between the two representative octahedral cations of biotite, $\mathrm{Fe}$ and $\mathrm{Mg}$, is negative. Although the explanations of high negative value of $\mathrm{Fe}-\mathrm{K}$ and high positive value of $\mathrm{Mg}-\mathrm{K}$ are not clear, the fact may suggest that the vermiculitization process is controlled partly by the $\mathrm{Fe} / \mathrm{Mg}$ ratio of the initial biotite, i.e., the higher the ratio the larger the $\mathrm{K}$ release resulting in further alteration to vermiculite. These correlation coefficients described above increase clearly when samples are restricted to the river sands (Table 3).

Multiple correlations between the analyzed elements should be also examined and for this purpose, the data of the numbered 32 samples in Table 1 were used. For the calculations, weight percent was converted to ppm and all the measured units were unified. Figure 6-A shows $\mathrm{Zn}$ and $\mathrm{Li}$ ratios among the minor elements of the octahedral cations. As seen in the figure, $\mathrm{Zn}$ and $\mathrm{Li}$ show reverse correlation with each other, i.e., the loss or gain of $\mathrm{Zn}$ is compensated by $\mathrm{Li}$ and vice versa. This relation clearly indicates that $\mathrm{Li}$ occupies the octahedral position. Correlations between the major octahedral cations, $\mathrm{Fe}, \mathrm{Mg}$ and $\mathrm{Mn}$, are shown in Fig. 6-B. Among these elements, $\mathrm{Fe}$ and $\mathrm{Mg}$ correlate well with each other and the $\mathrm{Mn}$ ratio is almost constant in the range between 0.01 and 0.03 . The results clearly indicate that $\mathrm{Fe}$ in biotite is substituted by $\mathrm{Mg}$. Multiple correlations among the possible interlayer cations are shown in Fig. 6-C. As seen in the figure, $\mathrm{K}$ and $\mathrm{Na}$ are well correlated with each other. The variation tendency of $\mathrm{Ca}$ is almost similar to that of $\mathrm{Na}$. These intimate relations were not found by the examinations of correlation coefficients between two elements. The $\mathrm{Rb}$ contents are relatively small and the ratio between the interlayer cations is almost constant in the range between 0.004 and 0.016 .

\section{ConClusions}

Metal contents of altered biotite collected along the Nishiki river, southwest Japan were measured and the relation between the metal contents and the geology of the district and correlation coefficients were examined. Biotite in the river sands are derived from the granitic rocks developed in the district, and the metal contents of biotite in the river sands show, in general, intimate relations to those of biotite in the parent granite. However, no special relation between the geology and the metal content of biotite is found during the transportation in the river water. Partial alteration of biotite to vermiculite with small amounts of vermiculitechlorite interstratified minerals is commonly observed in rivers and even in the parent granite.

Concentrations of the most representative interlayer cation, $\mathrm{K}$, depends on that of biotite in the parent granite and the loss or gain of $\mathrm{K}$ is intimately related to the alteration of the mineral. Among the interlayer cations, $\mathrm{K}$ correlates well with $\mathrm{Na}$ and $\mathrm{Ca}$ and $\mathrm{Rb}$ fraction is almost constant.

Characteristics of the possible octahedral cations can be summarized as follows: Substitution of $\mathrm{Fe}$ by $\mathrm{Mg}$ is commonly observed. Among the minor elements, $\mathrm{Cu}, \mathrm{Zn}$ and $\mathrm{Pb}$ contents vary locally and the local enrichments of these ions are caused probably by some human activities. Examinations of the correlation coefficients between any two elements suggest that a part of $\mathrm{Fe}$ and $\mathrm{Zn}$ is contained in the interlayer position.

In conclusion, biotite in the district is commonly altered to vermiculite and vermiculitechlorite interstratified minerals to some extent keeping the morphology of biotite even in the parent granite. Moreover, each granite has different rate or different extent of vermiculitization. The main variation of major elements in these altered biotite can be explained as the results of the alteration and decomposition. In the river sands, grain size of biotite becomes gradually smaller from the upper to the lower reaches, but the alteration process exhibits no further progress. However, minor element contents of both interlayer and octahedral cations change complicatedly depending on the local environments.

Acknowledgement-This research was supported in part 
by Grant in Aid for Scientific Researches from the Ministry of Education in Japan.

\section{REFERENCES}

Brindley, G. W. (1961) Kaoline, serpentine and kindered minerals. In the $X$-ray identification and crystal structures of clay minerals, 51-131. Edited by G. Brown. Miner. Soc. London.

Deer, W. A., Howie, R. A. and Zussman, J. (1962) Rock-forming Minerals 3, 55-84. Longmans, Green and Co. London.

Fisher, R. A. (1963) Statistical methods for research workers. Oliver \& Boyd Ltd. London.

Förstner, U. and Müller, G. (1974) Schwermetalle in Flüssen und Seen. Springer Verlag: Heidelberg.

Foster, M. D. (1963) Interpretation of the composition of vermiculite and hydrobiotite. Clays Clay Miner., Proc. 10th Natl. Conf. 70-89.

Harward, D. E. and Brindley, G. W. (1965) Swelling propoerties of synthetic smectites in relation to lattice substitutions. Clays Clay Miner. 16, 437447.

Iwakuni City (1979) Pollution of Iwakuni City. No. 11 (Japanese).

Mason, B. (1966) Principles of geochemistry. John
Wiley: London.

Nagasawa, K. (1972) Alteration of micas during weathering. Kobutugaku Zasshi 10, 528-539 (Japanese).

Nishimura, Y. (1971) Regional metamorphism of the Nishiki-cho district, southwest Japan. J. Sci. Hiroshima Univ. Ser. C 6, 203-268.

Nishimura, Y. (1982) Geologic age of Yamaguchi Prefecture determined by radioactive dating. Geol. Soc. Yamaguchi Prefecture No. 10, 1-8 (Japanese).

Ringwood, A. E. (1955) The principles govering trace element distribution during magmatic crystallization. Geochim. Cosmochim. Acta 7, 189-202. Sudo, T. (1974) Clay mineralogy. Iwanami: Tokyo. Takeno, S. (1965) A note on machinawite (so-called valleriite) from the Kawayama mine, Japan. Geol. Rept. Hiroshima Univ. No. 14, 59-76.

Takeno, S. (1966) Magnetometric and rontgenometric studies of pyrrhotite from the Kawayama mine, Japan. J. Sci. Hiroshima Univ. Ser. C 5,113156.

Takeno, S., Minami, A. and Kakitani, S. (1981) Heavy metal concentration to clay minerals in aqueous solutions (1) Suspension $\mathrm{pH}$ and metal contents of sericite. Kozan Chishitsu (Mining Geol.) 31, 443456. 